\title{
The Knights of Science: Medicine and Mythology
}

When parasitologist Joseph Dutton died of African Relapsing Fever on 27 February 1905, his obituary in the British Medical Journal concluded:

He was a true Knight of Science [... the Galahad of that group of enthusiastic young men who, with so little recompense for themselves, have pushed forward the cause of tropical medical science at such a rapid rate. ${ }^{1}$

The accolade 'Knight of Science' reflects tellingly on the author, fellow parasitologist Ronald Ross, and gestures more broadly to the romantic construction of scientific research at the fin de siècle. The implication here is that Dutton, who helped elucidate the aetiology of relapsing fever and discovered one of the causative agents of African sleeping sickness (the parasite Trypanosoma brucei), fought on behalf of science, risking his own life to propagate and advance tropical medicine as a discipline. Ross frames Dutton as the legendary knight, Sir Galahad, and scientific discovery as the holy grail of Arthurian romance. By populating the discipline, not with researchers squinting over microscopes, but with heroes performing mighty deeds, Ross situates parasitology research within a set of ideals about British imperial citizenship. Colonial administrator Sir William MacGregor drew on a similar rhetoric to lionise the profession in an

\footnotetext{
${ }^{1}$ Ronald Ross, 'Joseph Everett Dutton, M.B., Ch. B. Vict, D.P.H.' British Medical Journal 1.2314 (1905) 1020-21 (p. 1021).

(C) The Author(s) 2022

E. Taylor-Pirie, Empire Under the Microscope, Palgrave Studies in

Literature, Science and Medicine, https://doi.org/10.1007/978-3-030-84717-3_2
} 
address given at the London School of Tropical Medicine in 1900, 'you will in all probability be able to establish the existence of maladies at present unknown and unrecognised [...] can any man desire greater glory?' he asks. ${ }^{2}$ The 'glory' associated with scientific research, particularly research in the colonies, was a concept propagated by its association with the broadening of frontiers (both figurative and literal), but-for Ross-an unfulfilled ideal that he struggled with his entire career.

In his Memoirs (1923), Ross recalls 'a witty friend of mine once remarked that the world thinks of the man of science as one who pulls out his watch and exclaims: "Ha! half an hour to spare before dinner: I will just step down to my laboratory and make a discovery!"'3 Real science, however, is not such a brief or haphazard practice. This unrealistic image of success is precisely the reason he proposes for writing his Memoirs, which includes - as the subtitle boasts - a 'full account of the great malaria problem and its solution'. He regards the public's delusions regarding the man of science as a fault of the profession; "who, but men of science themselves are to blame for such a misconception?' he writes, criticising the history of discovery as a 'record of results' that eschews 'that sacred passion for discovery that leads to them' (vi). Notwithstanding this claim, it is predominately this 'sacred passion' that we see so carefully stagemanaged by proponents of parasitology and tropical medicine at the turn of the nineteenth into the twentieth century. Dangerous quests, hellish landscapes, and epic battles became the guiding metaphors for conceptualising the work of parasitologists, who-in political speeches, lectures, eulogies, journalistic essays, professional correspondence, and popular biographies-developed what amounts to a kind of modern epic poetics that framed parasitology as a story of heroic deeds performed by brave men.

In this chapter, I investigate how proponents of parasitology helped to embed a form of heroic masculinity in scientific research that still has currency in historiographical accounts of medicine today. As I explore, the rhetorical formulation of what I call the 'knights of science' narrative was informed by medieval chivalry, the warrior ideal, and heroic figures from Greco-Roman mythology. The medieval revival-marked by the enormous popularity of the historical novels of Walter Scott, as well as

\footnotetext{
${ }^{2}$ William MacGregor, 'An Address on Some Problems of Tropical Medicine' British Medical Journal 2.2075 (6 October 1900) 977-84 (p. 978).

${ }^{3}$ Ronald Ross, Memoirs; with an Account of the Great Malaria Problem and its Solution (London: John Murray, 1923) pp. v-vi.
} 
numerous paintings, poems, romances, histories of chivalry, and moral instruction manuals-played a key role in the Victorian and Edwardian social and moral imagination. As historian M. Gregory Kendrick has noted, medieval knights were 'heirs of Greco-Roman [...] tradition' and 'the Virgilian notion of the warrior hero as a loyal and selfless servant to his people [...] resonat[ed] through the centuries to come'. ${ }^{4}$ By drawing on these historical models, parasitologists extended what Kendrick refers to as "Greco-Roman "heroic imperialism" to their discipline, using ancient Greece, the legends of King Arthur, and exploits of past empires to situate British parasitology in relation to an idealised national identity. The myths and metaphors that parasitologists appropriated in their public rhetoric and private correspondence became stories about nationhood that sought to instil western scientific authority in narratives of British imperial progress and create a modern mythology that celebrated the work of 'great men' of science.

In 1850, Robert MacKay had observed that 'a remnant of the mythical lurks in the very sanctuary of science'. ${ }^{5}$ The notion that the mythical 'lurks' within science suggests that it does not belong there, or is not wantedleft over from the bygone days of prescience, or as Ross terms it nescience. ${ }^{6}$ However, this remnant of the mythical is not just lurking, but fully integrated into turn-of-the-century tropical medicine. As I demonstrate here, and throughout this book, fact and fiction are not polar opposites but rather complementary forms of knowledge that work together to inform our experiences of the world. The need to legitimise a newly emerging field of study, in addition to the desire to gain public support and funds, encouraged parasitologists to engage with the imaginative politics of nationhood. By appropriating iconic mythic narratives, parasitologists were able to communicate the practical and ideological importance of their work in ways that spoke to the public's desire for an authoritative, stable, and idealised national identity, updating the chivalric ideal in light of modern medical science.

\footnotetext{
${ }^{4}$ M. Gregory Kendrick, The Heroic Ideal: Western Archetypes from the Greeks to the Present (Jefferson: McFarland, 2010) p. 70; p. 23.

${ }^{5}$ Robert William MacKay, The Progress of the Intellect, as Exemplified in the Religious Development of the Greeks and Hebrews, vol II (London: John Chapman, 1850) p. 172.

${ }^{6}$ Ross, Philosophies (London: John Murray, 1911) pp. 4-5. Ross refers to the 'crime of nescience', which he aligns with 'irrationalism' and 'fakhirism'. However, for Ross, mythic language and imagery can be used to support science, as long as the science itself is based on empirical, reproducible experimentation.
} 


\section{ArThur AND EMPIRE}

When parasitologists were gaining their professional status at the turn of the century, two significant movements had risen to prominence in popular culture. The first of these, reflected in the proliferation of colonial adventure stories and the infiltration of empire as a plot device in British horror, detective, spy, and romance fiction, was the shifting power play of Britain's imperialist agenda. ${ }^{7}$ Following the 'Scramble for Africa' in the 1880s, discussions of empire were beset by questions of moral, political, and commercial viability. One prominent obstacle to expansion, and one that parasitologists sought to highlight, was the problem of tropical illness. As Ross would assert in a lecture given at the University of Liverpool and reprinted in the Journal of the African Society in 1905, 'the ever present endemic diseases' of tropical regions are not only deleterious to health, but 'paralyze administration $[. .$.$] paralyze commerce [. .$.$] vastly increase$ the cost and dangers of military expeditions; and check the missionary and explorer on the threshold of the countries which they come to open up'. ${ }^{8}$ Father of tropical medicine and Ross's mentor Patrick Manson (1844-1922) argued that the systematic teaching of tropical medicine was particularly important to Britain 'because our country is at the centre of a great and growing tropical empire'. And yet, as practitioners had bemoaned for decades, students of medicine before 1900 received almost no formal training to prepare them for the diseases that they might meet in the colonies and must instead learn by 'dearly bought experience' at the expense of patients' lives. ${ }^{10}$

\footnotetext{
${ }^{7}$ Victor Sage, arguing that the Gothic is 'the history of a set of cultural responses, not a genre', sees the late nineteenth century as producing a specific iteration of anxiety fiction called 'Empire Gothic'. See: Victor Sage, 'Empire Gothic: Explanation and Epiphany in Conan Doyle, Kipling, and Chesterton' in Creepers: British Horror and Fantasy in the Twentieth Century ed. by Clive Bloom (London: Pluto Press, 1993) pp. 3-23; Yumna Siddiqi recognises empire as a central plot device in a category of detective and spy fiction, which she calls 'fiction of intrigue'. See: Yumna Siddiqi, Anxieties of Empire and the Fiction of Intrigue (New York: Columbia University Press, 2008).

${ }^{8}$ Ronald Ross, 'The Progress of Tropical Medicine' Journal of the African Society 4.15 (April 1905) 271-89 (pp. 272-73).

${ }^{9}$ Patrick Manson, 'The Necessity for Special Education in Tropical Medicine' British Medical Journal 2.1919 (9 October 1897) 985-89 (p. 985).

${ }^{10}$ 'Ignorance of Tropical Diseases' British Medical Journal, 2.1774 (29 December 1894), 1491-92 (p. 1491).
} 
These professional concerns, as well as high death and invalidism rates among British missionaries and civil servants, precipitated the institutionalisation of tropical medicine in the Liverpool and London Schools of Tropical Medicine in 1898 and 1899, respectively. ${ }^{11}$ Both were associated with ports, which provided unique opportunities to study tropical diseases in Britain. As the Morning Post pointed out in 1901:

the patients come in direct from the ships on which they have fallen ill, so that the man who is going out presently to the regions where these diseases are common sees them here exactly as he will see them there, and so he leaves this country already a man of wide experience. ${ }^{12}$

Indeed, the visibility of illness at British ports was part of the reason the schools won support. The Liverpool school was established with funding and collaboration from local shipping merchants John Holt and Alfred Lewis Jones. Jones, who was president of the Liverpool Chamber of Commerce, had considerable commercial interest in the colonies via his steam ship company Elder, Dempster, and Co. (formerly African Steam Ship Company), which-in addition to facilitating trade with West Africa-supplied ammunition and cargo to the Belgian Congo and provided transport of British troops to South Africa during the AngloBoer war.

Jones understood the political significance of an English school dedicated to research and training in tropical medicine in the context of commercial trade. As a reviewer for Patrick Manson's popular textbook Tropical Diseases argued in 1898, knowledge of tropical medicine would 'be useful, not only to those who intend to practice in the tropics, but to those whose lines are cast in our seaports or on our ocean steamboats'. ${ }^{13}$ The London school, which was established with support from then Secretary of State for the Colonies Joseph Chamberlain, was similarly enmeshed within the politics of imperial finance, receiving a $£ 200$ donation from Belgian King Leopold II, in addition to government support. ${ }^{14}$ A few years later the school appealed for donations to fund new buildings

\footnotetext{
${ }^{11}$ The London school was later renamed the London School of Hygiene and Tropical Medicine.

12 'School of Tropical Medicine' Morning Post, Wednesday 6 November 1901, p. 4.

13 'Tropical Diseases: A Manual of the Diseases of Warm Climates by Patrick Manson' British Medical Journal 2.1959 (16 July 1898) 157-58 (p. 158).

14 'School of Tropical Medicine' Dover Express, Friday 28 April 1899, p. 3.
} 
and laboratories via the national press. Alongside various donations from businessmen, they received $£ 250$ from the Castle Union Steam Ship Company and a much publicised $£ 100$ from King George $\mathrm{V}$ in endorsement of their work. ${ }^{15}$

Chamberlain wanted to 'embrace the Greater Britain beyond the seas' and perceived tropical illness as a key obstacle to the global dominance of English-speaking Anglo-Saxons. ${ }^{16}$ Duncan Bell argues that Chamberlain 'retool[ed] patriotism' to support expansionist policies. We can certainly see this at work in regard to tropical medicine, which Chamberlain framed as a 'work of mercy' at a banquet hosted by the London School at Hotel Cecil in 1905. To be associated with the work of tropical pathologists was 'a privilege and a duty [...] which [Britain] owed the empire', he asserted, and 'however violently [MPs] might be opposed on political matters, they could join hands in this useful work':

We owed this duty to the vast population for which we had gradually made ourselves responsible, and we owed it still more to those of our own race who were daily risking health and life in order to maintain the honour and interests of this country.

Finally, in asking for support, he appealed to 'national pride and Imperial patriotism'. ${ }^{17}$

Chamberlain's emphasis on patriotic duty became a common rhetorical strategy that conceptualised the institutionalisation of formal schools of tropical medicine and parasitology in relation to British imperial progress. Tropical medicine provided the empire with a secular moral purpose that might be extended as not only a national duty, but a global one. At the same time, expansionist politics enabled parasitologists to raise the profile of their research and gain government funding and support. To this end, the progress of tropical medicine as a discipline was decisively tied to imperial politics and to the notion that the success of the British Empire relied on systematic knowledge of tropical disease. Thus, a writer for the British

15 'London School of Tropical Medicine' Belfast News-Letter, Friday 1 November 1912, p. 3; 'London School of Tropical Medicine' Nottingham Evening Post, Tuesday 22 October 1912 , p. 7.

${ }^{16}$ Quoted in Duncan Bell, Dreamworlds of Race: Empire and the Utopian Destiny of AngloAmerica (Princeton: Princeton University Press, 2021) p. 285.

17 'London School of Tropical Medicine' Aberdeen Journal and Press, Thursday 11 May 1905 , p. 6. 
Medical Journal in 1898 was able to claim that 'the enemy of civilisation and colonisation in Africa is not so much Mahdism as malaria'. ${ }^{18}$ This placed tropical disease on a par with anti-imperial resistance movementsa juxtaposition that politicised disease and insisted that medical research was fundamental to imperial administration. Indeed, the work of parasitologists was often made synonymous with the functional infrastructure of empire, as when William MacGregor drew an analogy between parasitologists and construction workers: 'It appears to me to be more or less like this: Manson ${ }^{19}$ was the surveyor, Laveran ${ }^{20}$ made the road, Ross ${ }^{21}$ built the bridges and laid the rails, and Grassi, ${ }^{22}$ Bastianelli, ${ }^{23}$ Bignami, and Celli provided the rolling stock'. ${ }^{24}$ Deborah Neill has emphasised tropical medicine's reliance on transnational networks in which ideas, theories, and people circulated. Notwithstanding the nationalist rhetoric that I analyse in this chapter, the elucidation of malaria was augmented-as MacGregor's analogy implies - by relationships between British, German, French, Italian, and American researchers that were competitive or collaborative as the occasion suited. As Neill argues, 'European tropical medicine experts successfully built a network of professional researchers and clinicians that helped them establish their collective authority as experts in a new field of scientific inquiry'. ${ }^{25}$

The second movement to register its prominence in popular culture was the, by this time well established, medieval revival, following the publication of Tennyson's Idylls of the King between 1859 and 1885 (which sold 10,000 copies within the first week) and the first modernisation of Malory's compilation of Arthur's tales, which had six further editions and

\footnotetext{
18 'Medicine in the Tropics' British Medical Journal 1.1955 (1898) 909-10 (p. 909).

${ }^{19}$ Sir Patrick Manson discovered the mosquito vector for the parasitic disease elephantiasis or lymphatic filariasis.

${ }^{20}$ (Charles Louis) Alphonse Laveran discovered the protozoan parasite responsible for malaria (Plasmodium spp).

${ }^{21}$ Ronald Ross traced the life cycle of the Plasmodium parasite into the stomach of the mosquito and proved that the mosquito acted as a vector for avian malaria.

${ }^{22}$ Giovanni Battista Grassi demonstrated conclusively the vector transmission of malaria in humans and established that only the female Anopheles mosquito can transmit the disease.

${ }^{23}$ Giuseppe Bastianelli, Amico Bignami, and Angelo Celli studied the clinical symptoms of Plasmodium falciparum and recognised several stages of the development of malaria parasite within the blood.

${ }^{24}$ MacGregor, 'Some Problems of Tropical Medicine', p. 980.

${ }^{25}$ Deborah J. Neill, Networks in Tropical Medicine: Internationalism, Colonialism, and the Rise of a Medical Specialty, 1890-1930 (Stanford: Stanford University Press, 2012) p. 3.
} 
five competitors before the century ended. ${ }^{26}$ As Mike Horswell has noted 'crusader medievalism' occupied a central place within the British imaginary 'due to its ability to incorporate key cultural trends: it could serve the Romantic medieval revival, as well as aggressive imperialism and militant "muscular" Christianity'. ${ }^{27}$ Chivalry and crusading flooded the Victorian imagination as concepts that could engage with a wide range of issues, including nationalism, imperialism, domesticity, race, and gender. ${ }^{28}$ The hugely popular historical fiction of Walter Scott did much to demonstrate the dramatic potential of the crusades and helped to institute chivalry as an 'important pillar of British imperial identity'. ${ }^{29}$

As I argue, parasitology became another crusading fiction, which practitioners manipulated to construct their professional identities, journalists invoked to communicate research developments, and proponents weaponised to justify expansionist policies. Between 1898 and 1914, the Liverpool School of Tropical Medicine sent 13 expeditions to the tropics, including to Sierra Leone, the Gold Coast, Nigeria, Brazil, French Senegal, and the Congo Free State. ${ }^{30}$ The West African Mail reported on these expeditions using emotive titles such as 'The Crusade against Tropical Disease and the Liverpool School of Tropical Medicine'. An article in Good Words likewise referred to Liverpool researchers as 'crusaders', and another in the Sheffield Daily Telegraph reported on Ross's work as 'the crusade against malaria'. ${ }^{31}$ Journalists similarly styled Joseph Chamberlain's involvement in the London and Liverpool schools of tropical medicine as

${ }^{26}$ David Staines, 'Tennyson, Alfred Lord' in The New Arthurian Encyclopaedia ed. by Norris J. Lacy (New York: Garland, 1996) pp. 446-49.

${ }^{27}$ Mike Horswell, 'Creating Chivalrous Imperial Crusaders: The Crusades in Juvenile Literature from Scott to Newbolt, 1825-1917' in Perceptions of the Crusades from the Nineteenth to the Twenty-First Century. Engaging the Crusades, vol 1 ed. by Mike Horswell and Jonathan Phillips (London: Routledge, 2018) pp. 27-47 (p. 27); Mark Girouard writes about a popular revival of chivalry throughout the nineteenth century that infiltrated diverse areas of middle-class life including education, politics, imperial administration, and sports. See: Return to Camelot: Chivalry and the English Gentleman (New Haven: Yale University Press, 1981).

${ }^{28}$ Megan L. Morris, 'Introduction: Victorian Crusades Literature' ([n.d.]) The Crusades Project https://d.lib.rochester.edu/crusades/text/nineteenth-century-literature-introduction [accessed 26 October 2020].

${ }^{29}$ Mike Horswell, 'Creating Chivalrous Imperial Crusaders', p. 31.

${ }^{30}$ D. H. Molyneux, 'The Liverpool School of Tropical Medicine: 100 Years of Parasitological Achievement' Parasitology Today 14.11 (1998) 440-43.

${ }^{31}$ Herbert Hamilton 'Fighting Malaria' Good Words 43 (December 1902) 188-93; 'The Crusade Against Malaria' Sheffield Daily Telegraph, Monday 2 September 1901, p. 5. 
his 'crusade against malaria', whilst Regius professor at Oxford Sir William Osler was named a 'health crusader' by one Scottish newspaper, which informed readers that he was constantly 'crusading against malaria and typhoid'. ${ }^{32}$ In 1921, The Daily Telegraph reported on the 'War on Disease' being fought by tropical medicine experts worldwide and particularly by the Rockefeller Foundation. Winston Churchill, then Secretary of State for the Colonies, reportedly characterised the work as a 'crusade of mercy [...] wonderful crusades [...] marching not only on the path of science but on the path of mercy'. The study of tropical diseases was carried out, he argued, with an urgency 'similar to that which prompted men to hurry to the sea coast on a stormy night and take the lifeboat out to a ship in distress'. ${ }^{33}$ Crusading was a concept, as Horswell notes, that could be 'woven into a triumphal national story which culminated in an imperial nationalism'. ${ }^{34}$

References to crusading, particularly via the sea, were a characteristic component of both the public discourse and private conceptions of tropical medicine research. The revival of Arthurian legend, the popularity of travel writing, the visibility of explorers as cultural icons, and the burgeoning market for fictions of adventure provided rhetorical resources with which parasitologists conceptualised both the study and the mechanics of parasite-vector-host relationships. In letters to Manson, Ross invokes a quest motif by insisting that he will 'follow the flagella' and 'pursue the plasmodium', paralleling symbolically the parasite's migration through its hosts, the letters themselves on their travels from Ross in India to Manson in England, and the expeditions of both contemporary tropical explorers and legendary figures like King Arthur's knights. Using the trope of heroic campaign, Ross compares research to expedition by setting up parallels between the movement of parasites between and within hosts, and the conquest of foreign lands. Manson reiterates this use of the quest motif in a letter dated $21^{\text {st }}$ June 1895 :

I look forward to receiving [your letters] with the greatest interest and when a mail passed without getting one the other day I was terribly disappointed for I thought you had fallen sick, or that you had got a check, or that you

32 'Personal Gossip' Evening Star and Herald, Saturday 13 May 1899, p. 2; 'A Health Crusader. Life of William Osler' Aberdeen Press and Journal, Monday 18 May 1925, p. 3.

33 'War on Disease' Daily Telegraph, 14 June 1921, n.p.

${ }^{34}$ Mike Horswell, The Rise and Fall of British Crusader Medievalism, c. 1825-1945 (London: Routledge, 2018) p. 3. 
had given up the quest. Above everything, don't give it up. Look on it as a Holy Grail and yourself as Sir Galahad and never give up the search. ${ }^{35}$

As we have seen, Ross would use the Galahad reference again when eulogising Joseph Dutton in 1905. The Times would later characterise Ross's work in kind as a 'quest' in which he was 'so long and so gallantly' engaged, and which produced a legacy that 'glows with an imperishable lustre'. ${ }^{36}$ Manson's use of crusading tropes in private correspondence and MacGregor's glorification of the profession to medical students suggests that what I have called the 'knights of science' narrative was not simply a rhetorical strategy but also an ideological position. Ross first met MacGregor at Liverpool in 1899 and was present at his London medical address in 1900. In his Memoirs, he writes, '[O]f all the men I have met I honour him the most' (444). MacGregor would characterise Ross's research in 1901 as 'unique and glorious labours'. ${ }^{37}$ Whilst MacGregor promised 'glory' to the young tropical pathologist, a writer for the British Medical Journal promised 'novelties and surprises' which should 'prove highly attractive to the student grown stale over the threadbare subjects and over-refinements of European pathology'. ${ }^{38}$

In reimagining their research in terms of the hero's quest, parasitologists drew on and reinforced a cultural association between Arthurian legend and British expansionism. Stephanie Barczewski argues that supporters of British imperialism used the King Arthur legend to demonstrate that 'Britons have for centuries looked outwards towards their burgeoning empire and territorial expansion', associating a celebrated and venerated history with a promising imperial future. ${ }^{39}$ She identifies the prominence of the sea (fundamental to colonial travel and commerce) in nineteenthcentury reinterpretations of Arthurian romances as a motif that connects mythic journeys with imperial trade. Parasitologists consciously

${ }^{35}$ Patrick Manson, 'Letter 11. 02/004' in The Beast in the Mosquito: The Correspondence of Ronald Ross and Patrick Manson ed. by W.F. Bynum and Caroline Overy (Amsterdam: Rodopi, 1998) pp. 31-33 (p. 31).

36 'Sir Ronald Ross' The Times, 17 September 1932 [n.p.].

${ }^{37}$ William MacGregor, 'Notes on Anti-Malarial Measures Now Being Taken in Lagos' British Medical Journal 2.235 (27 July 1901) p. 680.

38 'Medicine in the Tropics' British Medical Journal 2.1969 (24 September 1898) 909-10 (p. 910).

${ }^{39}$ Stephanie L. Barczewski, Myth and National Identity in Nineteenth-Century Britain (Oxford: Oxford University Press, 2000), p. 201. 
strengthened this association by representing themselves as embarking on ocean expeditions to explore unknown lands, and fighting valiantly against adversity to protect the empire, not with the sword, but with science.

Elly McCausland argues that, at the turn of the century, British and American adaptations of Arthurian adventure for children sought to 'promote and subtly redefine chivalric masculinity for the modern age'. ${ }^{40}$ Modern conceptions of knightly boyhood were situated in dialogue with the 'soldier hero of adventure', which Graham Dawson identifies as 'one of the most durable and powerful forms of idealised masculinity'. ${ }^{41}$ In these fictions, and in boy's groups like the Scouts, there is, McCausland argues, 'a curious juxtaposition between a modern vision of 'gentleman', divested of its class connotations, and adherence to a medieval value system far removed from contemporary British and American society'. ${ }^{42}$ The formative role of medievalism and imperialism in this type of masculinity is made explicit by Baden-Powell's original desire to name the Scouts the 'Young Knights of the Empire'. ${ }^{43}$

Parasitologists sought to emulate standards of medieval chivalry by emphasising not only appetite for adventure, but the more stoic virtues of duty, perseverance, and self-sacrifice. In 1932, the Rover Scouts-developed in 1918 for those men who had outgrown the Boy Scouts-declared Ross a 'worthy role model', as reported by 'Scout News' in the Coventry Evening Telegraph. 'In this man's life', they wrote, 'is an example of selfsacrificing service for Rover Scouts to follow' ${ }^{44}$ Astronomer and soon-tobe editor of Nature, Richard Gregory published Discovery; or the Spirit and Service of Science in 1916 in which he argued that 'worthy intention' shaped the discipline as much as 'brilliant achievement'. ${ }^{45}$ Taking his cues

\footnotetext{
${ }^{40}$ Elly McCausland, “Something Which Every Boy Can Learn”: Accessible Knightly Masculinities in Children's Arthuriana, 1903-1911' in Martial Masculinities: Experiencing and Reimagining the Military in the Long Nineteenth Century ed. by Michael Brown, Anna Maria Barry, and Joanne Begatio (Manchester: Manchester University Press, 2019) pp. 214-31 (p. 215).

${ }^{41}$ Graham Dawson, Soldier Heroes: British Adventure, Empire, and the Imagining of Masculinities (London: Routledge, 1994) p. 1.

${ }^{42}$ Elly McCausland, 'Something Which Every Boy Can Learn', p. 220.

${ }^{43}$ Stephen Arata, Fictions of Loss at the Victorian Fin de siècle: Identity and Empire (Cambridge: Cambridge University Press, 1996), p. 94.

44 'Scout News. A Worthy Example. Sir Ronald Ross' Coventry Evening Telegraph, Tuesday 20 September 1932, p. 4.

${ }^{45}$ R. A Gregory, Discovery; or the Spirit and Service of Science (London: Macmillan and Co., 1916), p. vi.
} 
from the chivalric masculinity that characterised tropical medicine at the turn of the century, Gregory insisted that the qualities of 'self-sacrifice, persistence, courage, duty, accuracy, humility and hope may all be abundantly exemplified from the careers of men of science' (vii). Under a section entitled 'Conquest of Disease' he asserted that 'laud and honour' should be given to the 'patient scientific investigators' of tropical medicine and reprinted some of Ross's poetry, perpetuating a narrative of one man set against 'million-murdering death' (225-26). When Ross reviewed Discovery for an issue of his journal Science Progress in 1917, he asserted that it had become 'a classic between the date of issue and the date of review', dubbing the book 'a true history of mankind' ${ }^{46}$

Gregory found ample material in the recent history of tropical medicine to demonstrate the virtues of the soldier hero. Writing of Dr Lazear, who died during an experiment with yellow fever, he asserts:

He gave up his life for others, and the plain record of his sacrifice upon a tablet erected to his memory reads: "with more than the courage and devotion of the soldier he risked and lost his life to show how a fearful pestilence is communicated and how its ravages may be prevented". (228-29)

Gregory informs us that Dr Walter Myers also faced that 'fearful pestilence' and lost to it:

His death added another name to the roll of martyrs to scientific investigation. High courage and an unselfish spirit led him to accept the invitation to take part in a most dangerous expedition; and he died that others might live. $(230)$

Such imagery engages with a semantic project of professional selffashioning that characterised tropical medicine as a new manful science of empire, where individuals were always brave and the stakes were always high. ${ }^{47}$ Whilst writers frequently mobilised the metaphors of military warfare to do this, just as often they invoked the knightly adventure-a

\footnotetext{
${ }^{46}$ Ronald Ross, 'Discovery; or The Spirit and Service of Science by R. A. Gregory' Science Progress, 11.44 (April 1917) p. 691.

${ }^{47}$ Heather Ellis explores efforts to revitalise the public image of the man of science throughout the century, arguing that the authority of science stemmed from an unstable conception of masculinity that was constantly under threat. Heather Ellis, Masculinity and Science in Britain, 1831-1918 (London: Palgrave Macmillan, 2017).
} 
powerful image of one man up against an unassailable foe. This, and frequent appeals to myth, enabled parasitologists to distance their profession from the more unsavoury aspects of imperial administration.

Nathan K. Hensley points to the number of wars throughout the century (at least 228 separate armed conflicts) at a time often remembered for its 'progressive idealism', as precipitating an uncanny persistence of violence in cultural productions. ${ }^{48}$ Hensley investigates the representational strategies that communicated to readers the problematic fact that 'peacekeeping and war-making were not separate ideas but two aspects of sovereign power' (2). The rhetoric of turn-of-the-century tropical medicine might be considered one such representational strategy. The martial language used by parasitology's proponents was offset by the purported goal of producing a lasting and peaceful civilisation. Moreover, they often utilised an idealised, older form of military encounter in which the pathogen 'foe' was conquered by an archetypally heroic (and often lone) figure, shifting the focus of imperial violence from the colonial subject to 'colonial' disease - a placeholder for the imagined barbarism of colonial space. Their 'triumphs' were frequently communicated using a fairy-tale lexis of sword fighting, dragon slaying, and giant killing. Thus, despite parasitology's visible political interests, parasitologists were reimagined as figures engaged, not in the unsavoury wars of contemporary Britain, but in legendary battles. For example, following a lecture on Ross's mosquitomalaria work given at the Bath Pump House in 1924, Rev J. C. Harris reportedly said that in listening to Ross's work, they had heard 'a new version of the old story of George and the dragon'. ${ }^{49}$ Meanwhile another writer insisted that Ross 'fought a pitch battle, single-handed, against an invisible dragon which has slain millions of human beings, the malarial parasite' and that 'just when he was abandoning hope, he found-in the stomach of the thousandth mosquito-the dragon he sought'.$^{50}$

Parasitologist William G. MacCallum also drew on this mythic apparatus when writing about discoveries in parasitology for the West Australian in 1932: 'Old legends and fairy-tales tell us of battles with giants and dragons; modern medical science tells us of battles with microbes too

\footnotetext{
${ }^{48}$ Nathan K. Hensley, Forms of Empire: The Poetics of Victorian Sovereignty (Oxford: Oxford University Press, 2016) p. 1.

49 'A Conquered Pest: the Mosquito and Malaria' Bath Chronicle and Weekly Gazette, Saturday 16 February 1924, p. 15.

50 'A Real Romance' The Sphere, 24 July 1926, p. 97.
} 
small to be seen' ${ }^{51}$ MacCallum, who discovered the male and female gamete forms of the malaria parasite in birds in 1897, described Ross's work on malaria using a by then familiar Arthurian framework:

Sir Gawain asked the knight if he knew any adventures in that country, "I shall show you some to-morn" said the old knight, "and these marvellous." So on the morn they rode into the forest of adventures. The forest of adventures for Sir Ronald Ross - then plain Major Ross of the Indian Medical Service-was the teeming insect life of India. At Secunderabad, on August 20th 1897, he made an epoch-making step into the unknown. ${ }^{52}$

The narration of a valiant knight hungry for adventure (and the colonial landscape as the land fit for this pursuit) positioned the tropical researcher as a hero of modern times, combining the historic virtues of chivalry and patriotism with contemporary concern for sanitary reform.

The central tensions inherent in this motif are articulated by Rudyard Kipling's poem 'The New Knighthood', which offers a stark juxtaposition between the courtly conventions of British orders of chivalry and the 'barbarism' of the colonial outpost. The poem, which appeared after a 'Deal in Cotton' in Actions and Reactions (1909), begins: 'Who gives him the Bath?/"I", said the wet/Rank, jungle sweat,/"I'll give him the Bath"'.53 Giving him the Bath refers to the practice of bathing knights-to-be in the Middle Ages as a symbolic spiritual purification-an act that gave its name to the Order of the Bath, an order of British military knighthood established by King George I in 1725. Garter King of Arms and England's highest heraldic officer, John Anstis, outlined the tenets of a knight of the Bath as

the exaltation of the Holy Christian Religion; the Support of the Rights of our Sovereigns; the Defence of their Realms; the Advancement of Justice; the Protection of Virgins, Widows, and Orphans; the Relief of the Oppressed; and for Demonstrating the Affection of our Monarchs towards the Estate of Chevalrie; to the End, both their Subjects and Foreigners may be rewarded

${ }^{51}$ W.G.M, 'The Deadly Female. Murder that Mosquito!' West Australian, Saturday 15 February 1938, p. 5.

${ }^{52}$ William MacCallum, 'Science and Poetry. Work of Sir Ronald Ross' West Australian, 13 February 1932, p. 5.

${ }^{53}$ Rudyard Kipling, Actions and Reactions (London: Macmillan and Co., 1909) p. 197. 
for Heroick Military Actions, and towards exciting other Persons to imitate such Examples.

Anstis concludes that the Order is founded 'upon religious, upon moral, and political considerations', an ideology that persisted in New Imperialist understandings of empire. ${ }^{54}$ Kipling's 'new knighthood' transplants the pomp and ceremony of medieval knighthood-which historically included ritual bathing, reading of psalms, laying of swords, buckling of spurs, and drinking of wine-to an archetypal tropics where 'jungle sweat', 'palms', 'hot wind', 'sun', 'short-rations', 'fever', and 'quinine' also play a role in the making of a knight.

Who'll shake his hand?

"I," said the Fever,

"And I'm no deceiver,

I'll shake his hand."

Who brings him the wine?

"I," said Quinine,

"It's a habit of mine,

I'll come with his wine". (197)

Bradley Deane argues that much of Kipling's poetry is concerned with the production of 'better men' through imperial toil. True to this appraisal, 'The New Knighthood' positions the struggle for manly self-assertion at the core of the expansion and defence of the British Empire. Deane argues that Kipling prizes 'valorized manliness' over biological maleness, and 'heritage' over 'race' as a way of motivating his readers to actively tread the road to 'better manhood' and avoid the complacency inspired by racial Englishness. Kipling encourages men to aspire to an 'English heritage constituted through competition for masculine honour [...which] demanded endless struggle and reaffirmation'. ${ }^{55}$ 'An ethos of honourable suffering' is one of many models that Kipling used to understand the global encounters of men-a model that was shared by proponents of

${ }^{54}$ John Anstis, Observations Introductory to an Historical Essay upon the Knighthood of the Bath (London: James Woodman, 1725) p. 3.

${ }^{55}$ Deane, Masculinity and the New Imperialism, p. 44. 
tropical medicine who saw Kipling's constant struggle for manly honour embodied in the science of empire. ${ }^{56}$

The poem's final lines-'And after this fashion, adventure to seek/Was Sir Galahad made—as it might be last week!'-invoke the same chivalric masculinity that Ross used to eulogise Dutton as a 'knight of science' in 1905 (albeit perhaps in a different tone). Both Ross and Kipling suggest that the work of imperial administration is a trial of endurance that finds a parallel in historical models of chivalry. According to Ross, Duttonwhose death, he insisted, was 'to all of us like that of a family bereavement'-demonstrated not only scientific ability, but 'a singular purity, modesty and courtesy of character'. He worked 'without rest or recreation, and in spite of frequent illnesses [...] unremittingly in the cause of science and his country'. ${ }^{57}$ Kipling's poem might as well have been written about Dutton. Indeed, the idea that Kipling had the work of parasitologists in mind when composing 'The New Knighthood' is certainly possible. Born in Bombay in 1865, Kipling knew India first hand. As a journalist and writer living in India between 1883 and 1889, and a regular visitor to South Africa, he had ample experience of empire and illness. But, more significantly, Kipling and Ross were friends and in the year of the poem's publication, they were in correspondence about setting up an annual dinner for British Nobel Prize winners (Kipling having won the Nobel in 1907 and Ross in 1902). In a letter dated $13^{\text {th }}$ May, Kipling noted that he had read Ross's 'speech on malarial (or lack of) prevention the other day with keen sympathy', suggesting he agreed with Ross's characterisation of imperial servants as underappreciated and their work as self-sacrificing. ${ }^{58}$ 'The New Knighthood' suggests that working in tropical colonies was equal to the knightly work of defending the realm and that the reward for such work was in short supply.

${ }^{56} \mathrm{~A}$ prominent counternarrative that criticised British expansionist policies, and particularly the human rights abuses most strongly associated with the Belgian Congo, can be read in much late-century fiction. The work of Joseph Conrad is a prime example, where scholars such as Lorenzo Servitje have read tropical illness as a signifier of 'coloniopathy' and the project of empire as sordid and degenerating. See: Lorenzo Servitje, "“Triumphant Health": Joseph Conrad and Tropical Medicine' Literature and Medicine 34.1 (2016) 132-57.

${ }^{57}$ Ross, 'Joseph Everett Dutton, M.B., Ch. B. Vict, D.P.H.', p. 1021.

${ }^{58}$ London, LSHTM. RC. GB 0809 Ross/86/07/01. Letter dated 13 May 1909. Two days later, he sent a further letter thanking Ross for sending him a copy of a lecture on malaria and professing a wish to read it in full. London, LSHTM. RC. GB 0809 Ross/86/07/01. Letter dated 15 May 1909. 
The promise of chivalry embodied by the imperial encounter in the popular imagination was realised for Ross when he was admitted into the Order of the Bath as a companion in $1902 .{ }^{59} \mathrm{He}$ was promoted to a Knight Commander in 1911 and in 1918 was also made a Knight Commander of the Order of Saint Michael and Saint George. Fellow doctor and poet Ronald Campbell Macfie (1867-1931) included a photograph of Ross in his 1907 book The Romance of Medicine, which he captioned 'Dr. Ronald Ross, C.B. The Hero of the Mosquito Theory of Malaria'. The photo and caption, which appear opposite a reprint of Ross's malaria day poem, 'Reply', do much to reinforce the popular conception of medical heroism that pervaded late-century feats of empire. Ross's medical work is, for Macfie, 'a romance in microscopy such as has rarely been equalled'. ${ }^{60}$

Ross won many honours and awards, including most notably his Nobel Prize (1902), and was a Fellow of the Royal Society and Royal College of Surgeons; however, Macfie only includes his companionship (denoted by C.B.). Thus, he makes use of the system of military and civic honours to reinforce Ross's claim to heroism, a claim also bolstered by the reproduction of his poem on the opposite page. Ross's poem recasts his discovery as a heroic moment ordained by God: 'Seeking His secret deeds/with tears, and toiling breath/I find thy cunning seeds/O million-murdering death'. His years spent researching malaria as part of the Indian Medical Service-encapsulated by 'tears and toiling breath'-are rewarded in melodramatic fashion. Ross recounts his celebration: 'I know this little thing/A myriad men will save,/O Death, where is thy sting?/Thy victory, O Grave!' His invocation of Corinthians endorses a mid-century muscular Christianity that came to characterise the idealised colonial encounter, as I will explore in the next chapter, and perpetuated an image of scientific

\footnotetext{
${ }^{59}$ Many parasitologists received similar honours from British orders of chivalry; David Bruce (1855-1931) was made a Companion of the Order of the Bath (C.B.) in 1905, Knight Bachelor in 1908 (K.B.), and Knight Commander (K.C.B.) in 1918; Samuel Rickard Christophers (1873-1978) was made a Companion of the Indian Empire (C.I.E.) in 1915; David D. Cunningham (1843-1914) was made C.I.E. in 1893; Robert Leiper (1881-1969) was made Companion of the Order of St Michael and St George (C.M.G.) in 1941; William Boog Leishman (1865-1926) was made C.B. in 1915, K.C.B. in 1924, and K.C.M.G. in 1918; Patrick Manson (1844-1922) was made Knight Commander of the Order of St Michael and St George (K.C.M.G.) in 1903, and Knight Grand Cross (G.C.M.G.) in 1912; Leonard Rogers (1868-1962) was made C.I.E. in 1911, and Knight Commander of the Star of India (K.C.S.I.) in 1932; Henry Edward Shortt (1887-1987) was made C.I.E. in 1941.

${ }^{60}$ Ronald Campbell Macfie, The Romance of Medicine (London: Cassell and Co., 1907) p. 146.
} 
research as a form of self-sacrificing heroism. Writing in 1947, a correspondent for the Belfast Telegraph recalled meeting Ross 'years after he had presented his gospel of healing to the world'. She demonstrates the lasting impression of the rhetoric of parasitology by reproducing the language of the discipline, writing about his 'indomitable spirit' and insisting that 'he went to his microscope as a knight of old rode to battle'. ${ }^{61}$

\section{Alexander, Shakespeare, and Apollo: Literary METAPHOR AND SCIENTIFIC IdEALISM}

The collection of mythic metaphors and images associated with parasitologists were not just used to bolster their public reputations but also deployed to mediate professional discussions. In an article concerning the aetiology of kala-azar, Surgeon-Major George Giles used a reference to Alexander the Great to lampoon a colleague's suggestion that the disease was a complication of malaria:

An ordinary man would indeed see at once that such a position is untenable, but Dr Rogers, like a medical Alexander, cuts his Gordian knot by announcing that Assamese malaria is infectious. In this he places himself at variance with not only the scientific, but the popular opinion of the entire world. ${ }^{62}$

Here Giles characterises Rogers's solution to the problem of kala-azar as analogous to Alexander the Great's severing of the Gordian knot. This analogy is a significant one, which itself requires some unpicking. Kalaazar is a parasitic disease, now predominantly known as visceral leishmaniasis, but at the time variously named kala-azar, kala-dukh, Burdwan fever, Blacktown fever, black fever, Dum-dum fever, or Assam fever. The aetiology of the disease was unclear and it shared many of its symptoms with malaria, leading some to argue that it was not a new disease at all but instead a complication of malaria or a quinine-resistant form of malarial poisoning. ${ }^{63}$ This was the position held by Surgeon-Captain Leonard Rogers, a member of the Indian Medical Service, who was sent to Assam in 1895 to investigate the disease. He went on to help establish the

${ }^{61}$ Kathleen Lurgan, 'From an Ulsterwoman's Scrapbook: Founder of "Mosquito Day"” Belfast Telegraph, Wednesday 20 August 1947, p. 4.

${ }^{62}$ G. Giles, 'The Etiology of "Kala-Azar"' Indian Medical Gazette 33.1 (1898), p. 1.

${ }^{63}$ The causative agent- the protozoan parasite Leishmania donovani-was isolated independently by Charles Donovan and William Leishman in 1903. 
Calcutta School of Hygiene and Tropical Medicine in 1920 and was a founder member of the Royal Society for Tropical Medicine and Hygiene (1907).

Giles, also of the Indian Medical Service, argued that Roger's theory was flawed because malarial poisoning was not infectious and kala-azar was. ${ }^{64} \mathrm{He}$ instead attributed the disease to a combination of chronic malaria and the presence of ankylostomes (intestinal worms), which to his mind accounted for the prevalence of kala-azar within families and close social groups. However, Rogers posited a solution: that malaria found in the Assam region (where kala-azar was prevalent) is a special variety of the disease, which is infectious. Giles points out the short-sightedness of this position; whilst it indeed reaches a solution, it is not backed up by evidence and thus is like cutting the knot, rather than untying it.

The use of the Gordian myth reinforces the notion that parasitologists understood their profession using mythic past narratives. Alexander the Great, leader of the Macedonian Empire, was a figure of imperial might comparable to the leaders of the Roman, Byzantine, and Mughal Empires. ${ }^{65}$ Reference to such figures invoked past histories as models for the British pursuit of empire. Significantly, the decline of these great empires was often attributed to tropical disease. Such was the strength of this belief that Ross even collaborated with William Henry Samuel Jones and George Grigson Ellet on Malaria: A Neglected Factor in the History of Greece and Rome (1907). In the preface, Jones argued that malaria posed a unique danger to civilised nations:

Most other diseases, however distressing to individuals, brace a people by weeding out the unfit; malaria plays no such useful part in the economy of nature. It seizes all, fit and unfit alike, gradually lessening the general vitality until, in some cases, it has exterminated the people among whom it has become endemic. ${ }^{66}$

${ }^{64}$ Both were eventually found to be transmitted by insect vectors-mosquito and sandfly respectively - and thus neither truly infectious.

${ }^{65}$ When discussing Tennyson's 1892 poem 'Akbar's Dream', Patrick Brantlinger argues that 'Akbar is an Oriental King Arthur' and suggests that Tennyson uses this parallel to prophesize the triumph of the Empire: 'The great work he [Akbar] has begun of civilizing the Indian wilderness will collapse, but the British will take it up again and complete it on a permanent basis'. Patrick Brantlinger, Rule of Darkness: British Literature and Imperialism, 1830-1914 (Ithaca: Cornell University Press, 1988) p. 10.

${ }^{66}$ W. H. S. Jones, Ronald Ross, and G. G. Ellet, Malaria: A Neglected Factor in the History of Greece and Rome (London: Macmillan and Co., 1907) p. vi. 
In the introduction, Ross similarly singles out the nation-levelling power of malaria, asserting:

Historians, in attributing the downfall of nations to human agencies, have overlooked the probably greater effects produced by those obscure or invisible foes that destroy us from within $[\ldots]$ the conqueror of Greece was not so much the Macedonian or the Roman as that great tyrant which now holds half the world-malaria. (5)

Using quantitative data analysis of malaria rates in modern Greece, and qualitative data analysis of the uses of malaria-related terms in Ancient Greek medical and cultural texts, the writers make a case for its historical endemicity. Jones, for example, finds evidence that malaria was an ancient problem in Hippocrates' observation that those who drink marsh water have an enlarged spleen. ${ }^{67}$

Despite ascertaining that malaria was probably prevalent in ancient Greece, Jones insists that it is 'an African disorder' that entered the country following the 'intercourse of merchants', the return of sick soldiers, and the migration of slaves. His characterisation aligned modern Britain with ancient Greece through imperial trade and conquest. However, where past empires had failed Britain's would not because the nineteenthcentury model was endowed with a secret weapon: tropical medicine. Unlike the great empires that came before, Britain's focus was purportedly on successfully colonising (rather than simply conquering) foreign lands and thus on effective and lasting solutions to the problems of parasitic disease. For Giles, this success was analogous to truly unravelling (rather than cutting) the Gordian knot.

In a 1916 article in Science Progress, Ross considered the parallels between science and literature, arguing that 'the great histories and biographies, as well as other epics and novels, belonged to the same class of work' as those of science-that is-work that is aimed at educating the non-specialist. He dubbed Homer, Dante, Shakespeare, and Cervantes 'great men of science' who were each 'in his own country and epoch' engaged in 'collecting, classifying, and cataloguing the infinite varieties of character and circumstance in human life'. This 'sub-science' attempted to

\footnotetext{
${ }^{67}$ Splenomegaly, or abnormally enlarged spleen, is a symptom of malarial infection. Jones notes that, in connecting enlarged spleen to marsh water, Hippocrates was unknowingly identifying the connection between malaria, marshland, and mosquitoes-the vectors of malaria.
} 
'extract from the facts an explanation for human action'. 'The only manner in which science can be taught to men', he argued,

is by way of narratives of events which, though they may not actually have occurred as described, are occurring over and over again in history and in our lives-just as Euclid's book was the first to crystallise geometry in sets of definite propositions with figures which are never actually found in nature. ${ }^{68}$

In other words, linear story-telling is the mode in which humans can best understand new ideas. Likewise, 'the constructions of the men of science', he asserted, 'have to be idealised, partly for brevity and partly for fixing the attention of the public'. In both cases, science relies on art for its 'presentment' (137).

These different modes of knowledge, literary and scientific, fictive and non-fictive, were also mobilised to establish the value and nature of scientific research, as exemplified by an obituary of parasitologist Walter Myers. Myers, who worked alongside Ross at the Liverpool School of Tropical Medicine, died of yellow fever whilst investigating the disease in 1901. He was remembered with a brief memorandum of his life and work in 1913, which ended with the line: 'The Rest is Silence'. Not content with this reference to Hamlet, the Financial News, in republishing the memorandum, saw fit to add the following lines from Tennyson's In Memoriam, a poem in which Tennyson tries to come to terms with the death of his close friend Arthur Henry Hallam at the age of just 22:

So here shall silence guard his fame;

But somewhere, out of human view,

Whate'er thy hands are set to do,

Is wrought with tumult of acclaim. ${ }^{69}$

The dual frames of Shakespearean tragedy and what is considered one of the great poems of the nineteenth century positioned Myers' death within a framework of tragic loss, both frames emphasising the poetic nature of scientific endeavour. Barri J. Gold argues that Tennyson embraces poetry 'as a way of knowing', whilst maintaining an investment in scientific modes

${ }^{68}$ Ronald Ross, 'Homer, Dante, Shakespeare, and Cervantes' Science Progress, 11.41 (July 1916) $137-40$ (p. 137).

${ }^{69}$ Alfred Tennyson, from 'In Memoriam A.H.H.' quoted in 'How to Assist Tropical Medical Work’ Financial News, 23 January 1913. n.p. 
of inquiry. She argues that In Memoriam insisted on the 'consonance of the "two cultures" of science and literature at a moment when they seemed to be diverging'.$^{70}$ Gold identifies the poem as disrupting dominant models of unidirectional influence (science to poetry) by drawing our attention to the prescience Tennyson shows regarding theories of Darwinian evolution and thermodynamics. In Memoriam, she argues, anticipates these fields of knowledge and thus is an example of ideas moving from literature to science, not only circulating facts but 'helping them to exist'. ${ }^{71}$

The use of the poem to eulogise Walter Myers reaches into the past to connect two premature deaths and lament lost potential across multiple spheres of knowledge. It also contributed to the framing of scientific figures and their achievements using the cultural authority of literature. The eulogy was part of an article asking for financial support for research in tropical medicine, and the lines from In Memoriam were included to 'tell the reader in what spirit and at what cost the work is being done'. Or as Ross puts it to 'fix the attention of the public'. Such collaborative relationships between literature and science complicate ideological and disciplinary boundaries-boundaries that Ross often rejected wholesale. As he argued in a lecture given at the Royal Institution and reprinted in the English Review, both disciplines are motivated by the same desire to know. He writes:

Do you really imagine that science is concerned only with the discovery of petty utilities; art with the discovery of new tricks of technique? [...] art is science teaching us, not by means of saws and syllogisms, but by means of wise instances and great figures set within crystals of perfect and immortal beauty. ${ }^{72}$

For Ross, art and science walk 'hand in hand' as a Keatsian dialogic of 'beauty' and 'truth'; 'we shall reach Truth by seeking Beauty; and Beauty by Seeking Truth. Nor shall we attain one without the other', he insists. ${ }^{73}$

${ }^{70}$ Barri J. Gold, Thermopoetics: Energy in Victorian Literature and Science (Cambridge: MIT Press, 2010) pp. 35-36.

${ }^{71}$ Gold, p. 3.

${ }^{72}$ Ronald Ross, 'Science and Poetry' English Review (October 1920) 303-19 (pp. 306-07).

${ }^{73}$ Ross, 'Science and Poetry' English Review, p. 319. Such a philosophy was drawn from his interest in ancient Greece and Rome, which he admired as models of civilisation. In his Memoirs, he characterises his malaria work as an episode precipitated by his boyhood interest in ancient Greek philosopher Epicurus and Roman poet and philosopher Lucretius. 
It is possible to map Ross's goal of a blended art and science onto his interest in the Greek muses, to whom he frequently refers. In his science and poetry lecture, he asserts 'the figures of Apollo, Pallas Athene, and the Muses are the personifications of the intellectual virtues' ${ }^{74}$ His insistence on viewing the world in these poetic terms-in his own words, a 'Heliconian philosophy' - was gently mocked by Arthur Conan Doyle in his poem 'To Ronald Ross' ${ }^{75}$ The poem was inspired by Ross's visit to Parnassus after being torpedoed by the Germans onboard a ship near Ithaca:

I've read of many poets, Latin, Greek,

And bards of Tarragona or Toledo,

But you, dear Ross, are surely quite unique,

Blown to Parnassus by a Boche torpedo. ${ }^{76}$

In his Memoirs, Ross also recalled this incident through the lens of Greek mythology, although seemingly without irony. He notes that in the aftermath of the first torpedo, he went down below ship to retrieve his heavy military overcoat with 'Sir J. G. Frazer's Studies in Greek Scenery, Legend, and History and Baedecker's Greece in its pockets'. ${ }^{77}$ Following which he reappeared on deck in time to witness the second torpedo and escape with the rest of the crew and French soldiers into a waiting destroyer. As Ross describes the military stand-off between the French destroyers and the German submarine, he diverges into an altogether different narrative:

The rising sun was like Apollo in the east, and the rippled sea as blue as heaven. We were all wild with delight. I said to myself: "Ulysses and Penelope must be seated on Ithaca there, watching the scene". (521)

Ross's obsession with ancient Greek models of intellectual creativity-and the philosophical positions that they embody-clearly informed his worldview (not to mention his narrative style) in substantial ways. Such was the significance of mythological narratives for Ross that he saw fit to end his Memoirs somewhat arbitrarily with the scene related earlier. Observing the landscape that surrounds him, he concludes: 'there, as of yore, were the

\footnotetext{
${ }^{74}$ Ross, 'Science and Poetry' English Review, p. 319.

${ }^{75}$ Ross, Memoirs, p. 497.

${ }^{76}$ Arthur Conan Doyle, 'To Ronald Ross' in The Poems of Arthur Conan Doyle (London: John Murray, 1922) p. 216.

${ }^{77}$ Ross, Memoirs, p. 520.
} 
Great Gorge and the Castalian Cleft; but now the temple was nothing but a pavement, the treasures were empty, the gods had become mountain eagles, and the voice of the pythoness was the voice of the wind' (522). He asks the Oracle of Delphi for the cause of all human troubles and is rewarded by Apollo's voice 'in the wind'. What follows is another of Ross's poems, which speaks of men who 'would not be taught', before a curt 'so ends my story'. These bitter sentiments reflect his belief that the British and colonial governments had not done enough to stem the spread of malaria, despite knowing its full aetiology. A footnote tells us that Ross provided 'an account in verse' of this military event during a lecture to the Royal Institution in 1920. Ross concluded the lecture with the assertion 'science and poetry dwell together'. Rejecting 'militarism', 'politicism', and anti-intellectualism as 'false gods', he instead urges his audience to worship the 'figures of Apollo, Pallas Athene, and the Muses [who] are the personifications of the great intellectual virtues which have raised us from the barbaric state' ${ }^{78}$

Despite his criticism of imperial governance, Ross subscribed to the idea that British imperialism was a civilising influence. In his Memoirs, he again employs the mythic forms of ancient Greece, this time to conceptualise hill stations. Speaking of the British in India he writes:

They introduced honesty, law, justice, order, roads, posts, railways, irrigation, hospitals, defence from external enemies and, what is essential to civilisation, a final superior authority. But they themselves dwelt apart like the gods. (17)

The gods provide a way of characterising the power dynamic between British colonists and indigenous Indians-the former's 'final superior authority' akin to the absolute power of mythic deities.

\section{Descent into the East: Tropical Mythologies}

Ross was not unique in reaching back to the narrative power of ancient Greece. Indeed, owing in part to the emphasis on classics in the education system in the nineteenth century, and in part to the perception that Classical Greece provided the foundations for western civilisation, ancient

\footnotetext{
${ }^{78}$ Ronald Ross, 'Science and Poetry' English Review (October 1920) 303-19.
} 
Greek mythology formed a common reservoir for medical analogy. ${ }^{79}$ The mythic Greek hero provided a connection to past civilisations and empires, myth being for the ancient Greeks 'the major formative power of cultural progress' ${ }^{80}$ Frank Turner argues that, for the Victorians, Greek civilisation represented not 'the Ancients', but 'distant contemporaries who had confronted and often mastered the difficulties presenting themselves anew to the nineteenth century' ${ }^{81}$ To this end, their myths were repurposed for scientific analogy; the mythic Greek hero was often fused with the Knight Errant (a figure associated with Britain's Arthurian myths of nationhood) to better represent the tribulations of the British Empire.

In an address on the tropics and the nation, Regius professor of medicine at Oxford, William Osler, identified three outstanding events in the making of the modern world: 'the Greek civilisation, the geographic renaissance of the sixteenth century, and the scientific awakening of the nineteenth century'. The latter, he asserted, 'has given man such a control of nature that at a stroke is removed the chief obstacle to world-wide dominion' ${ }^{82}$ In 1898, Dr Luigi (later Louis) Sambon had identified this obstacle as a belief in the immutability of the tropical world. He, like so many of his contemporaries, saw parallels between ancient Greece and modern Britain and used a figure from Greco-Roman mythology to contextualise the debate:

But there remains the great tropical belt, with its vast and rich territories extending over more than a third of the surface of the globe. This, surely,

\footnotetext{
${ }^{79}$ Frank Turner argues that the classical world was at the heart of Victorian intellectual thought. See: Frank Turner, The Greek Heritage in Victorian Britain (London: Yale University Press, 1981) p. xii.

${ }^{80}$ Walter Burkert, Structure and History in Greek Mythology and Ritual (Berkley: University of California Press, 1979) p. xii.

${ }^{81}$ Turner, p. xii.

${ }^{82}$ William Osler, 'An Address on the Nation and the Tropics' The Lancet (13 November 1909) 1401-06 (p. 1401). In 1906, Osler had invited Ross to give a lecture before the Oxford Medical Society, in which Ross had elaborated his theory that the fall of ancient Greece was predominantly due to the introduction of malaria into the population. Osler introduced Ross to William Henry Samuel Jones with whom he wrote Malaria: A Neglected Factor in the History of Greece and Rome (1907). Jones dedicated his 1909 Malaria and Greek History to Ross 'as a tribute to his labours for the welfare of mankind'.
} 
must be the Promised Land; but we dare not enter, because at its gates stands a terrible monster-the Cerberus of prejudice. ${ }^{83}$

Sambon mobilised this analogy to dispel the erroneous notion that Africa could not be colonised by 'the white man' owing to geographical or ecological incompatibility. He refers here specifically to the popularly held connection between tropical climate and disease: 'It is the almost universal opinion that the European cannot colonise the tropics, but must inevitably fall, sooner or later, a victim to the influence of their deadly climate'. ${ }^{84}$ He went on to point out the folly of this connection, highlighting the importance of new medical knowledge: ${ }^{85}$

One time, undoubtedly, these diseases were attributed to the direct and sole agency of solar heat, just as malarial fevers were attributed to the moonshine; but now they have been inscribed deeply on the tablets of bacteriology, and certainly the demonstration that disease belongs to the domain of parasitism is the greatest advance that medical science has ever made. (589)

Sambon's use of Cerberus (the three-headed, serpent-tailed hound of Hades) characterises the tropics as the Underworld and the journey across the Atlantic as tantamount to crossing the river Styx (a formidable stretch of water that separates the Earth from the Underworld). Nevertheless, Sambon also refers to the tropical belt as 'the promised land' perhaps to draw an analogy to the belief, expressed in the Aeneid, that Elysium was located in a special region of the Underworld. ${ }^{86}$ To achieve Elysium-or to unlock the commercial potential of the tropics-Britons must persevere through the barrenness and hardships of the African continent, symbolised by the Underworld. However, before the British can find Elysium (or happiness in Africa), they must first also lull to sleep the Cerberus of Prejudice, that is, they must dispel the notion that the tropics are uninhabitable. ${ }^{87}$ Patrick Manson used the same analogy in 1907; however,

${ }^{83}$ L. Westernra Sambon, 'Acclimatization of Europeans in Tropical Lands' The Geographical Journal 12.6 (1898) 589-99 (p. 589).

${ }^{84}$ Sambon, 'Acclimatization of Europeans in Tropical Lands', p. 589.

${ }^{85} \mathrm{He}$ is in fact so against this climatic connection that he insists 'sunstroke' is not caused by exposure to the sun, but is an infectious disease.

${ }^{86}$ Robin Hard, 'The Brothers and Sisters of Zeus' The Routledge Handbook of Greek Mythology (London: Routledge, 2004) p. 117.

${ }^{87}$ The sibyl accompanying Aeneas on his journey through the Underworld puts Cerberus to sleep by tossing him a drugged honey cake, whilst Orpheus uses a harp to lull Cerberus 
his Cerberus was not prejudice but disease: 'The Cerberus that guards the African Continent, its secrets, its mystery and its treasure is disease... (which I would liken to an insect)' ${ }^{88}$ The final clause suggests that Manson refers specifically to parasitic diseases, many of which have insect vectors.

Manson's and Sambon's gatekeepers are effectively one and the same; the prejudiced notion that Africa is uninhabitable to Europeans stems from a direct association between climate and disease. Both regarded the taming of disease as the key to colonisation. Sambon advocated a disassociation between heat and disease, as he saw no causative link between them. As the British Medical Journal reported in 1897:

Like everyone else, Dr. Sambon recognises two [obstacles to tropical acclimatisation] heat and disease. But he differs from almost everyone else in accentuating the fact that these two are $[\ldots]$ independent of each other; in fact entirely distinct. ${ }^{89}$

This dissociation dispelled the notion that tropical lands were noxious environments in and of themselves, suggesting that a third factor (the parasite) is what causes disease, and thus what might be overcome by Europeans. Europeans cannot change the tropical climate, but they might be able to avoid parasitic infestation and thereby achieve acclimatisation. As a writer for the British Medical Journal concluded in 1898:

If climate pure and simple be the cause of the unhealthiness in the tropics, the position is hopeless; we cannot materially modify climate. But after all it is mainly the parasites $[\ldots]$ take away the malaria microbe and the dysentery microbe from West Africa and this deadly country would become as healthy as Europe. ${ }^{90}$

into submission when he descends to the Underworld to rescue Eurydice. Elizabeth Webber and Mike Feinsilber (eds.) 'Cerberus' in Merriam-Webster's Dictionary of Allusions (Springfield: Merriam-Webster, 1999) p. 107; George William Cox, Tales from Greek Mythology (London: Longman, Green, Longman and Roberts, 1861) p. 20.

${ }^{88}$ Quoted in Sheldon Watts, Epidemics and History: Disease, Power and Imperialism (Bath: The Bath Press, 1997) p. 213.

89 'Europeans in the Tropics' British Medical Journal 1.1880 (9 January 1897) 93-94 (p. 93).

90 'Medicine in the Tropics' British Medical Journal 2.1969 (24 September 1898), 909-10 (p. 910). 
In this way, parasitologists were again indirectly valorised by their insistence that the only thing standing in the way of European acclimatisation was parasitic disease and, by extension, the only ones able to grant acclimatisation were parasitologists.

The transformative powers of parasitology and its allied practices of public health and sanitation were an integral part of the parasitology brand-a highly politicised modern mythology constructed by and about its proponents. The playfulness of this mythology can be seen in correspondence between Ross and Lord Lever (later Leverhulme)-benefactor of the Liverpool School of Tropical Medicine and manufacturer of Sunlight Soap. Lever wrote to Ross in 1911 to inform him that he had received a drama in one act, anonymously signed, which had St Peter send 'a soapmaker', billed as the chair of the School of Medicine, and 'a scientist', who 'made a great discovery', to Hell. He enclosed the play and composed a second act, which he provided under the authorship of 'a certain soapmaker' who 'often gives rise to reflections'. ${ }^{91}$

The scientist is clearly a fictionalisation of Ross and the soap-maker of Lord Lever.92 Given the subtitles: 'by a scientist' and 'by a soapmaker', respectively, it seems likely that Ross composed the first act and Lever the second. The gathering of applicants who are 'mostly from Liverpool, Shipowners, Professors, Business Men and so on' situates the drama in dialogue with the Liverpool School of Tropical Medicine and its proponents. ${ }^{93}$ The first act takes place at the 'Gates of Paradise' where St Peter is reviewing the applicants for admittance to heaven. After meeting a Parson and sending him to Hell for the insincerity of his prayers and his failure to convert anyone to Christianity, St Peter is met with a scientist.

St Peter: $\quad[\ldots]$ Next. Who are you?

Scientist: A poor man of science, Sir.

St Peter: Oh! I don't understand that lot. What has he done?

Secretary: He made a discovery once, Sir-many years ago.

\footnotetext{
${ }^{91}$ London, LSHTM. RC. GB 0809 Ross/113/20/05. Lever to Ross, 27 December 1911.

${ }^{92}$ William Lever was an English industrialist and philanthropist best known for manufacturing (with his younger brother) 'Sunlight Soap'-a business that relied on palm oil supplied by the British Empire.

${ }^{93}$ From the tone of the correspondence and the details of the play, which take place 'Christmas 19-' and conclude with many LSTM members getting into Heaven 'because it is Christmas Day', I suspect the first act was sent by Ross to Lever as a private joke.
} 
St Peter: Ah yes, I've read about it in our Science Jottings. And what has he discovered since then?

Secretary: Nothing, Sir.

St Peter: Monstrous! Why not? Why haven't you used your talent?

Scientist: Please, Sir, I have had to spend all my time writing letters, attending committees, and dining with the next applicant; so that I have had no leisure to think and work properly.

St Peter: Rot! Down you go. Fifth class. ${ }^{94}$

These lines might be read as an allegory for the mistreatment of scientists, a reading that is supported by Ross's campaigns for better recognition and remuneration for scientific workers. Scottish scientist Henry Faulds, commenting on Ross's remuneration campaign, captured this sentiment when he asked:

Why should only well-paid warriors, diplomats and civil servants be additionally requited for often purely conventional services, while those who painfully penetrate with ultimate success into the unknown, but fertile regions receive nothing for their expenses, and often not even the barest form of thanks? $?^{95}$

By using the concept of 'penetrat[ing]' into 'unknown but fertile regions', Faulds upholds the widespread characterisation of research in parasitology as a physical expedition. The speed with which St Peter dismisses the scientist's discovery suggests both a belittling of the significance of his research and a lack of understanding of the political nuances and administrative red tape associated with such work. ${ }^{96}$

Alternatively, the scene might be read as a sincere criticism of the amount of time spent reaping the rewards of discovery at dinners and committees, by someone who, either seriously or teasingly, Lever accuses

\footnotetext{
${ }^{94}$ London, LSHTM. RC. GB 0809 Ross/113/20/07-08. 'The Gates of Paradise', 27 December 1911.

${ }^{95}$ Henry Faulds, 'The Reward of Research' British Medical Journal, 1.2781 (18 April 1914), p. 888 .

96 'It seems to me there is far too much red tape in these matters and that an ordinary layman like myself is in much greater danger of damaging the cause he wishes to help [...] if he rushes in where angels fear to tread'. London, LSHTM. RC. GB 0809 Ross/121/01. Lever to Ross, January 1912.
} 
of 'lay[ing] sacrilegious hand on the scientist'. ${ }^{97}$ Either reading, however, suggests a disparity between the perspectives of the workers of the Liverpool School of Tropical Medicine and their political reception at large. Faulds's notion of scientists as penetrating into unknown lands and subsequently transforming them is played out in the second act, which has the scientist, parson, and soap-maker descend into the deepest regions of Hades. A conversation with 'his Satanic majesty' reveals that the Underworld has been positively transformed owing to St Peter's dislike of scientists, whom he sends to Hell, and who then proceed to improve it beyond recognition.

His Satanic Majesty: The fact is we get so many distinguished scientists that they are improving the place entirely out of my recollection. They introduce Town Planning Schemes, Garden Cities, Art Galleries, Museums; to say nothing of Tropical Wards, Scientific Medical Research and other advancements. ${ }^{98}$

Parallels with the tropics are erected through references to 'climate' (which has of course been improved by the scientists in Hades), and by references to other markers of colonial space. ${ }^{99}$ The journey to Hades takes place by train, perhaps nodding to the railway infrastructure of the colonies, a seminal factor in the successful colonisation of central Africa. Satan encourages further comparison when he says:

The very men who invented mosquito proof curtains have introduced here fire proof curtains $[\ldots]$ and there is one distinguished scientist connected with the Liverpool School of Tropical Medicine, whom we are expecting here shortly and whom we have good reason to believe has succeeded in inducing a very wealthy Baronet, living in the South of England somewhere near Ascot, to fit up a cold chamber on the Haslam Improved System. ${ }^{100}$

${ }^{97}$ London, LSHTM. RC. GB 0809 Ross/113/20/05. Lever to Ross, 27 December 1911. ${ }^{98}$ London, LSHTM. RC. GB 0809 Ross/113/20/07-08. 'The Gates of Hades', December 1911.

${ }^{99}$ Furthermore, Ross's assertion that '[Africa] is mostly an empire of graveyards, a kingdom over tombstones' allegorically links the colonies with Hade's underworld. London, LSHTM, RC. GB 0809 Ross/67/08. Ronald Ross, 'A Recent Medical Expedition to West Africa' lecture delivered at the Liverpool Chamber of Commerce on 27 November 1899.

${ }^{100}$ London, LSHTM. RC. GB 0809 Ross/113/20/07-08. 'The Gates of Hades', December 1911. 
This likely refers to Ross's work studying the effects of cold on animals (and people) infected with trypanosomiasis (African sleeping sickness). ${ }^{101}$ A cold chamber, made by Alfred Haslam, was erected at the University around this time, paid for by Edwin Durning-Lawrence. ${ }^{102}$

Parallels with recognisable real-life developments, like the implementation of mosquito nets in the tropics and the construction of the cold chamber at Liverpool, situate the drama firmly in dialogue with the politics of the discipline. Lever became chairman of the school in 1909 and, according to Ross, immediately added $£ 800$ to the school income. ${ }^{103}$ In their letter correspondence, Lever and Ross exchange veiled compliments, which — given the parallels discussed here-suggest they see British imperialism and the work of the Liverpool school as part of the same sanitising and transformative force. A self-congratulatory tone comes to the fore as their dramatic counterparts bleed into real life and the lines between Greek mythology and the mythology of the discipline become increasingly indistinct: 'You make me blush when you talk about the Ignominious soapmaker improving Hades. It is the new departure in Town Planning being carried out by men of science headed by R... R...' ${ }^{104}$

The transformative power of parasitologists exemplified here is an idealisation; despite providing the basis for prophylaxis against parasitic disease in the tropics, parasitologists could not guarantee the implementation of their findings. In the medical press and his Memoirs, Ross repeatedly recounts his frustrations at the government's failure to act on the mosquitomalaria connection, as well as time and money spent on what were, to his mind, unnecessary further experiments. In a letter to The Lancet, he wrote:

We must not forget that while we are considering academical details valuable lives are constantly being lost and that we are already in possession of facts solid enough to form a basis for practical action. ${ }^{105}$

${ }^{101}$ See: London, LSHTM. RC. GB 0809 Ross/110/62. Ross to Sir Alfred Lewis Jones, December 1911 .

${ }^{102}$ See: R. Ross and J. G. Thomson, 'Experiments on the Treatment of Animals Infected with Trypanosomes, by Means of Atoxyl, Vaccines, Cold, X-Rays and Leucocyte Extract; Enumerative Methods Employed (Preliminary Note)' Proceedings of the Royal Society of London. Series B, Containing Papers of a Biological Character 83.563 (1911) 227-34.

${ }^{103}$ Ross, Memoirs, p. 511.

${ }^{104}$ London, LSHTM. RC. GB 0809 Ross/113/20/06. Lever to Ross, 30 December 1911.

${ }^{105}$ Ronald Ross, 'A Forgotten Suggestion' The Lancet 155.4002 (12 May 1900) 1400-01. 
He also sent a memorial petition signed by several colleagues to Joseph Lister urging sanitary action, but laments that nothing came of it, observing — facetiously — that the colonial office 'appointed a Committee!' (421).

In addition to petitioning for more to be done with the findings of parasitology research, he also campaigned for better remuneration, recognition, and pensions for scientific workers. These petitions included widely read articles in the lay press, which resonated with the public. Several correspondents wrote to Ross in support: 'I have been very struck with your letter in "The Times" [...] I should be very pleased to add to such a fund ( $£ 500$ anonymously)'; 106 'I have just read your letter in today's "Times", I wish I could send a cheque worthy of such an object'. ${ }^{107}$ However, the campaign was also met with resistance, as voiced by this article in the Abolitionist in 1914:

The claims of "research" workers to have benefitted mankind are matched only by their insistent pleading for grants and complaints of inadequate payment $[\ldots]$ I fail to see what claim [they have] upon the public purse of this country. ${ }^{108}$

Such scepticism concerning the social value of parasitologists reinforced the need for their imaginative reconstruction. The use of tropes such as the chivalric knight, the brave explorer, and the lone hero in both private and public correspondence contributed to the dramatisation of the discipline-a dramatisation that served to glorify individuals and legitimise their fiscal demands. Andrew Balfour, director of the London School of Hygiene and Tropical Medicine, for example, drew on ancient Greek epic poetry to characterise the story of malaria sanitation in British Malaya as 'a medical Iliad' that 'shows what can be done when the right men and ample funds are forthcoming'. ${ }^{109}$ In his Memoirs, Ross invokes the biblical imagery of the Promised Land, a metaphor freighted with colonial overtones, to communicate the lasting value of parasitology research.

British physician Sir Joseph Fayrer, who was president of the Medical Board of the India Office from 1874 to 1895 , mobilised similar

${ }^{106}$ London, LSHTM. RC. GB 0809 Ross/119/27. A. F. Yarrow to Ross, 18 August 1913. Probably Alfred Fernandez Yarrow (1842-1932) of Yarrow Shipbuilding Works.

${ }^{107}$ London, LSHTM. RC. GB 0809 Ross/119/25. Lilian Glenny to Ross, 16 August 1913. 108 'Sir Ronald Ross and his Petition' Abolitionist 6.15 (1914) 126-28 (p. 126).

${ }^{109}$ Quoted by Malcolm Watson, 'Ronald Ross (1857-1932)' Science Progress in the Twentieth Century 27.107 (January 1933) 377-92 (p. 389). 
techniques when writing about tropical disease in his contribution to the multi-volume textbook $A$ System of Medicine (1897). He noted that 'Milton's description of a trying climate is amply illustrated in India':

For Hot, Cold, Moist and Dry, four champions fierce

Strive here for mast'ry and to battle bring

Their embryon atoms. Paradise Lost. ${ }^{110}$

Whilst Fayrer's chapter drew attention to the wide variety of climates in India and included large sections of topographical and statistical information, reviews of the textbook concentrated on his use of Milton, re-quoting him for their readers and encouraging them to approach India through a mythic literary lens. ${ }^{111}$ Arthur Bagshawe, director of the sleeping sickness bureau, also used mythic language when referring to the task of reducing the Glossina Palpalis (tsetse fly) population to suppress sleeping sickness in Africa, which he compared to the 'labour of Sisyphus'. ${ }^{112}$ Such archetypal images helped to conceptualise the perceived difficulty and significance of the task at hand, equating the development and administration of public health with the trials that characterise Judeo-Christian and ancient Greek theology.

\section{Fairy Tales ANd Afterlives}

The knights of science narrative - and its kindred variations - held cultural currency owing not only to its political utility but also to its rhetorical power. It capitalised on popular appetite for imperial adventure stories and appealed to a 'great man' model of history, which was advanced by historian Thomas Carlyle in the 1840s and popularised by the novels of Walter Scott, Charles Kingsley, and Thomas Hughes (as I will explore further in the next chapter). Writers who engaged with the medieval revival emphasised chivalry and the ethic of service as part of a model of public masculinity that was in turn co-opted by parasitologists to valorise their work. By manipulating and updating the historical and imperial 'hero' to suit their own ends, parasitologists upheld continuities between national values and

${ }^{110}$ Joseph Fayrer, 'On the Climate and Some of the Fevers of India' in A System of Medicine by Many Authors, ed. by T. Clifford Allbutt (London: Macmillan and Co., 1897) pp. 296-352.

111 'A System of Medicine by Many Writers' JAMA, 8 July 1897, p. 45.

112 'Annotations. The Suppression of Sleeping Sickness' The Lancet 173.4462 (6 March 1909) p. 701. 
codes of behaviour over time whilst destabilising boundaries between myth, legend, and historical record. Such a destabilisation expanded the narrative potential of parasitology from a nascent medical specialism to a source of folkloric national identity.

Newspapers were quick to take up the linguistic patterns offered by the profession. The Liverpool Echo asserted, 'Of many modern fairy-tales of science, none, perhaps, is more fascinating than the story of the formulation and ultimate verification of the mosquito-malaria theory'. ${ }^{113}$ The Brisbane Courier also participated in the fairy-tale-like construction of parasitology by noting (of Ross):

His fight against the malaria-carrying mosquito has been truly described as more romantic than any story of knight against huge dragon [...] this kindly knight was to show himself possessed of patience, imagination, determined and highly-developed reasoning power, and above all faith and courage. ${ }^{114}$

Even in private correspondence, the mythical nature of Ross's work prevailed; a friend congratulating him on the Nobel Prize wrote that 'it reads like a Fairy Tale and I hope it will all end in Fairy Tale fashion and that you \& Rosie will live happily ever after, and all your children grow up to marry princes and princesses'. ${ }^{115}$

In 1923, Frederick James Gould, writing for the British social democratic newspaper, Justice, used the story of Hercules to contextualise Ross's malaria work. In the newspaper's 'Monthly Talks with Young Citizens' segment, he insisted: 'you were earnestly requested not to believe a word of the legend of Hercules [...] now I invite you to believe every word of this brief account of one of the greatest discoveries in the history of civilisation'. ${ }^{116}$ Hercules was again used as a frame of reference in James Oram Dobson's biography Ronald Ross: Dragon Slayer, in which Dobson writes, '[Ross's] social sympathies, his passion for health, and his own restless energies and capacities found fulfilment in those weary years of

${ }^{113}$ [No title] Liverpool Echo, Monday 15 February 1909, p. 4.

114 'Sir Ronald Ross' Westminster Gazette', Thursday 10 December 1925, p. 6; 'Sir Ronald Ross, Famous Scientist Ill' Northern Star, Friday 16 August 1929, p. 3; 'Sir Ronald Ross' Brisbane Courier, Tuesday 20 September 1932, p. 10.

${ }^{115}$ London, LSHTM. RC. GB 0809 Ross/86/06/18. Letter of congratulation, 1902.

${ }^{116}$ F. J. Gould, 'XVII-Three Workers. Ronald Ross' Justice, Thursday 6 December 1923 , p. 5 . 
concentration on a task that was the labour of Hercules'. ${ }^{117}$ Given that one of Hercules's most prominent labours was the capture of the hell-hound Cerberus, more might be made of this allusion (Cerberus being, as we have seen, a motif invoked to represent the obstruction of white settlement in Africa by tropical disease). Allusions to Hercules might also owe something to his second labour: the destruction of Cerberus's 'sister' the Hydra of Lerna. The swamp-dwelling hydra is fabled to have poisonous breath and bile and was considered by some to be symbolic of malaria, as Ross pointed out in his Prevention of Malaria (1910). ${ }^{18}$

The use of tropes drawn from myth and legend was widespread in popular medical books, like Macfie's The Romance of Medicine (1907), in which he waxed lyrical about the 'imaginative aspect and romantic character of medical discovery'. He asserted that the mosquito-malaria story was one 'of such determination and heroism' that it was surely 'worthy to be styled romantic'. ${ }^{119}$ Macfie, who knew Ross personally, sent Ross a copy of the book in 1908, clearly seeking his approval. He contributed several articles to Science Progress under Ross's editorship, and his poems were favourably reviewed in the magazine's pages, where he was eulogised in 1931 as a 'heroic soul' with 'the heavenly gift of poesy'. ${ }^{120}$ In 1928, he again described Ross's discovery, this time (perhaps following Ross's lead) using Greco-Roman mythology and the Portuguese colonial empire as frames of reference:

His scientific demonstration that the entrails of a judge might be as full of treacherous death as the belly of the Trojan Horse has saved and will continue to save thousands of lives. His scalpel not only carved mosquitoes but cut the Panama Canal and opened up more territories to the white races than all the bloody swords of all the conquistadores. ${ }^{121}$

${ }^{117}$ J. O. Dobson, Ronald Ross: Dragon Slayer. A Short Account of a Great Discovery and of the Man Who Made it (London: Student Christian Movement Press, 1934) p. 101.

${ }^{118}$ Ronald Ross, The Prevention of Malaria (London: John Murray, 1910) p. 4.

${ }^{119}$ Ronald Campbell Macfie, The Romance of Medicine (London: Cassell and Co., 1907) p. 155.

${ }^{120}$ R.M.S., 'Obituary: Ronald Campbell Macfie, H.A., M.B., C.M., LL.D., Died June 9, 1931' Science Progress in the Twentieth Century 26.102 (October 1931) 269-70.

${ }^{121}$ Ronald Campbell Macfie, 'Poems by Sir Ronald Ross' The Bookman, 28 September 1928 , p. 315. 
In 1937, five years after Ross's death, Rev. T. McDougall of St Paul's Presbyterian Church gave a lecture on Ross's life and works in which he quoted The Times in stating that Ross 'slew the Dragon and delivered mankind from immemorial bondage'. He noted that he was indebted to Chamber's Encyclopaedia and to Dobson's biography for the matter used in the lecture, demonstrating the lasting and intersecting afterlives of Ross's mythological narratives. ${ }^{122}$ John Rowland's 1958 biography of Ross, The Mosquito Man, indulges in a similar rhetoric when describing his discovery as 'a story of adventure-adventure in far off lands, as well as the more familiar surroundings of hospitals in London and Liverpool'. ${ }^{123}$

Meanwhile, in his 1931 biography of Ross, English writer Rodolphe Louis Mégroz titled the chapter about Ross's malaria research: 'The Quest' (language that persists in articles about Ross on the World Health Organization and Centers for Disease Control and Prevention websites today). ${ }^{124}$ Mégroz dedicated his book to 'all true hero-worshippers and especially to I. Landreth-Walton who first sent me "Philosophies" to read'. This reference to the transformative moment of reading one of Ross's poetry collections indicates that Mégroz's own 'hero-worshipping' was significantly framed by Ross's poetic persona. He describes Ross as 'sustained by a combination of his poetic power and scientific imagination', and presents his poetry as 'look[ing] back in the spirit of an adventurer to the climax of that scientific pilgrimage' (29). Indeed, many writers-in biographies, obituaries, and newspaper columns-insisted on the significance of his polymathic nature: 'this musician, poet, mathematician, doctor, scientist, philosopher, author, had solved a mystery of the ages'. ${ }^{125}$ Although starting out as an indulgent linguistic fantasy to explicate and contextualise the practical interventions of their research, the mythic 'knight of science' became an archetypal figuration that obscured the foundations of tropical medical knowledge for years to come.

122 'Sir Ronald Ross's Discoveries. Brotherhood Address' Northern Star, 20 March 1937, p. 14.

${ }^{123}$ John Rowland, The Mosquito Man: The Story of Sir Ronald Ross (London: Lutterworth Press, 1958) p. 9.

${ }^{124}$ R. L. Mégroz, Ronald Ross: Discoverer and Creator (London: George Allen and Unwin, 1931).

125 'Men You Will Hear of When You Grow Up' The Children's Newspaper, 6 December 1919 , p. 4. 
At the opening of a memorial gate commemorating Ross's malaria work in Calcutta, Lord Lytton, governor of Bengal, gave a speech in which he spoke of Ross's work as a 'self-imposed mission' and remarked:

It is nothing short of miraculous that such results should have been obtained by the discovery of one man, and that he, almost unaided, should have been able to detect not only the means by which malaria is carried but also the means by which it can be prevented. ${ }^{126}$

This idea of Ross as lone and unaided was inaccurate-in Ross's own histories of malaria, he points out the long chain of events that led to his discovery, from the suspicions of 'the ancients', to the elucidation of parasite lifecycles in the mid-century, to various theories of transmission, to his experimental proofs. Moreover, he recognises the network of kindred discoveries that needed to happen: from Laveran's discovery that malaria was caused by an animal parasite (rather than 'vegetable bacteria'), to Manson's discovery of the mosquito vector for filariasis, to David Bruce's discovery that tsetse flies transmit trypanosomes between cattle, to William MacCallum and Eugene Opie's elucidation of the sexual stages of the malaria parasite, to his own identification of human malaria parasites in the salivary glands of mosquitoes and experimental proof of mosquitoes as vectors of avian malaria, to the final confirmation of transmission between mosquitoes and humans by Giovanni Battista Grassi, Amico Bignami, and Giuseppe Bastianelli. During a brief speech, he noted his indebtedness to Alphonse (Charles) Laveran ('my master'), Patrick Manson ('my sponsor'), surgeongeneral Harvey, then director-general of the Indian Medical Service (IMS), and 'subsequent work in India by Christophers, James, and Bentley' (121). This is not to mention his staff of laboratory assistants, which included Mahomed Bux and science graduate Kishori Mohan Bandopadhyay, who was awarded the King Edward VII Gold Medal in 1903 for his role in the discovery (although Ross omits mention of him in his Memoirs).

Lytton's words then are disingenuous. They erase indigenous people from the story of tropical medicine, an erasure that Indian author Amitav Ghosh radically reimagines in his 1995 novel The Calcutta Chromosome. The value of the contributions of indigenous Indians and Africans is evident in correspondence between European researchers. German

\footnotetext{
126 'The Ross Gate of Commemoration in Calcutta' Science Progress in the Twentieth Century 22.85 (July 1927) 116-21 (p. 118).
} 
microbiologist Robert Koch, for instance, noted that natives in German East Africa believed that malaria was caused by the bites of mosquitoes as a fact that supported his own work. ${ }^{127}$ Likewise, Ross informed AmericanBritish parasitologist George Nuttall in 1898 that 'in parts of both Africa and Assam the natives believe that mosquito bites cause fever' ${ }^{128}$ In discussing the practicalities of his experiments, Ross credited Bux with developing a technique for identifying the larvae of Anopheles mosquitoes and urged Nuttall when making use of the information in publications to 'give the credit $[\ldots]$ not to me but to Mahomed Bux (for whom I want the government of India to do something). I think it will prove to be an observation of very great importance'. ${ }^{129}$ Nevertheless, the diverse social and material networks that supported parasitology research were obscured in journalistic accounts of tropical medicine, which reproduced the idealism of the discipline by framing prominent figures like Ross as a 'lone hero' or a 'great scientific soldier' in a 'fight against a scourge that till he was in the field took an annual toll of millions of mankind'. ${ }^{130}$

The institutionalisation of the discipline in two major English cities, integral to politics and commercial trade, provided a public face and a platform from which to influence legislation and medical practice. The London and Liverpool Schools combined their scientific, medical, social, commercial, and political interests to produce two institutions that far surpassed Chamberlain's notion of a space for colonial medical training. The varying interests that contributed to the foundations of the schools also shaped the professional identity of parasitologists and the ways in which they-and others - talked about their research. In 1903, co-founder of the Liverpool school and shipping magnate Alfred Lewis Jones revealed the intertwinement of commercial business and tropical medicine when asserting 'if the men of the future [are] to have a chance of fighting the battle of commerce, they must be better trained in science'. ${ }^{131}$ Extending the military metaphor, the Lord Mayor of Liverpool identified the

${ }^{127}$ As relayed to Ross by George Nuttall in letter correspondence. London, LSHTM. RC. GB 0809 Ross/17 Letter from G. H. Nuttall, 25 September 1898.

${ }^{128}$ London, LSHTM. RC. GB 0809 Ross/17 Letter to G. H. Nuttall, 31 October 1898.

${ }^{129}$ London, LSHTM. RC. GB 0809 Ross/17 Letter to G. H. Nuttall, 28 April 1899.

130 'Liverpool' British Medical Journal 1.2192 (3 January 1903) p. 48; 'Ronald Ross (By

One Who Knew Him)' Yorkshire Post and Leeds Intelligencer, 19 September 1932, p. 8.

131 'Liverpool' British Medical Journal 1.2196 (31 January 1903) 285-86 (p. 285). 
importance of Ross's discovery as 'mark[ing] a stage of advance and success in the warfare which humanity was waging against disease and death'. ${ }^{132}$

Sir William Banks, however, framed research by Ross and Manson as a counterpoint to the 'excessive praise' of 'what had been done by foreigners', demonstrating a tension between national achievement and international collaboration that underscored much public debate. The narrative patterns of parasitology often framed British research in terms of a patriotic desire to out-do competing imperial nations, as reflected in Manson's written encouragement of Ross, which was focused, not on elucidating the problem, but elucidating it first:

It is evident the Italians are now on the scent. I do hope you will run into the quarry before them. Bignami is a clever little fellow and ambitious. Laveran is working up the Frenchmen. I do not hear that the Germans are moving, but they will and so will the Russians. Cut in first. ${ }^{133}$

Manson repeatedly urged Ross to be mindful of international competition: 'The Frenchies and Italians will pooh pooh it at first, then adopt it, and then claim it as their own. See if they don't. But push on with it and don't let them forestall you'. ${ }^{134}$ In 1895, Manson again warned Ross of increasing French and Italian interest, urging Ross to 'hurry up and save the laurels for Old England'. ${ }^{135}$

The British Medical Journal was similarly preoccupied with nationality in regard to malaria research, asserting in 1897 :

We hope that in this case at least the authorities will take care that the British pioneer in what is truly a medical Africa has not once more discovered

132 'Liverpool' British Medical Journal 1.2192 (3 January 1903) p. 48.

${ }^{133}$ Patrick Manson, 'Letter 48 02/018' in The Beast in the Mosquito: the Correspondence of Ronald Ross and Patrick Manson ed. by W. F. Bynum and Caroline Overy (Amsterdam: Rodopi, 1998) pp. 124-25 (p. 125).

${ }^{134}$ Patrick Manson, 'Letter 19 02/007' The Beast in the Mosquito, p. 55.

${ }^{135}$ Letter from Manson to Ross, 11 October 1895 qtd in Jeanne Guillemin, 'Choosing Scientific Patrimony: Sir Ronald Ross, Alphonse Laveran, and the Mosquito-Vector Hypothesis for Malaria' Journal of the History of Medicine and Allied Sciences 57.4 (October 2002) 385-409 (p. 392). 
territories for the better-subsidised Frenchman or German to step in and occupy. ${ }^{136}$

The concern here is that Britain will lose out to competing nations owing to a lack of government support and funding. This is an extension of what Michael Paris recognises as a widespread anxiety in the 1890s of 'the challenge of ambitious and aggressive continental empires actively seeking to topple Britain from her premier position in the imperial hierarchy'. ${ }^{137}$ If tropical disease was the primary obstacle to imperial expansion and successful trade, then Britain's dominance in parasitology could determine her dominance in global politics too.

In the popular imagination, there was often a nationalist inflection to discussions of Ross's discovery. Following the award of the Nobel Prize, he received correspondence from doctors seeking advice, researchers in allied disciplines congratulating him, would-be patients wanting diagnoses, and even fans wanting autographs. One correspondent sent him a poem she had written which talks about the impressive sight of Ross and fellow parasitologist Lt. Col. John William Watson Stephens crossing the Liverpool University quadrangle. As they cross the quad to reach the Thompson-Yates laboratories, 'haughty arts men' watch them enviously, 'with noses pressed against the glass', and engineers are shamed by such an 'inspiring sight'. It begins:

Here come-now glory be to God!

The colonels twain across the quad

And one is dreamy, pale and long

And one alert, and brown, and strong.

Just as fellow parasitologists Kinghorn and Montgomery were described by one newspaper as 'fine specimens of British manhood', Stephens and Ross took on the physical attributes of heroic figures in the public imagination. ${ }^{138}$ The poem continues:

136 'A Malaria Problem' British Medical Journal 2.1929 (18 December 1897) 1805-06 (p. 1806).

${ }^{137}$ Michael Paris, Warrior Nation: Images of War in British Popular Culture, 1850-2000 (London: Reaktion Books, 2000) p. 8.

${ }^{138}$ See: London, LSHTM. R.C. GB 0809 Ross/113/23/24. Cutting: 'Insect Borne Disease' Daily Graphic, 1907, n.p. 
To you the privilege we tender,

Of basking in reflected splendour,

So long as you will keep in mind-

(We do not wish to be unkind,

Or brag or boast or make a fuss)

That both of them belong to $\underline{\text { us! }}{ }^{139}$

Friends similarly wrote to congratulate Ross with the addendum: 'you have done the trick and I congratulate you heartily and I congratulate ourselves for do you not belong to us? And you are no Italian, French or German but a plain Briton!' ${ }^{140}$ The public could draw pride from Ross's status as a 'plain Briton' in the context of a cultural discourse that narrated the discovery of the mosquito vector of malaria as a triumph of mental and moral fortitude. Ross had not only won something for humanity, but he had also proven the superiority of British mettle. In the emotively titled 'Honour to Whom Honour Is Due', the editors of the British Medical Journal proudly declared:

The short article on Surgeon-Major Ronald Ross's most recent work on the mosquito in malaria, which we publish to-day, shows that in this particular line of investigation for once our countrymen have been observing, reasoning, and proving whilst their continental confréres were still only speculating. ${ }^{141}$

Indeed, the British Medical Journal routinely invoked the concept of nation when discussing gains in tropical medicine. In September 1898, for example, they had asserted that for years French, German, Italian, Japanese, and American researchers had grappled with questions of colonial disease whilst the British had 'listlessly disregarded' the subject. '[T]he naval and colonial services, the increasing body of medical missionaries, and the vast crowd of civil practitioners connected with our tropical possessions', they insisted, had been 'utterly neglected' in tropical education. However, Britain has a 'practical monopoly of medical opportunity', given her tropical possessions, and they are glad to report that 'Englishmen are

${ }^{139}$ London, LSHTM. RC. GB 0809 Ross/146/19/26. Poem sent by Miss Allman, 23 February 1919.

${ }^{140}$ London, LSHTM. RC. GB 0809 Ross/48/36. Letter dated 31 September 1898.

141 'Honour to Whom Honour is Due' British Medical Journal 1.1955 (18 June 1898) 1607-08 (p. 1607). 
now throwing off their lethargy [and] awakening to a sense of duty and responsibility'. ${ }^{142}$

This is an awakening that the British Medical Association, through its journal, branches, and individual members, felt they could 'justly claim to have contributed powerfully to'. They perceived evidence of British investment and growing interest in tropical medicine in the introduction of lectureships on tropical disease in metropolitan and provincial medical schools; several textbooks recently published on the subject; the appearance of the Journal of Tropical Medicine; a special section of dedication to tropical diseases by the association; and the founding of the London School of Tropical Medicine at the Albert Docks.

Although research in tropical medicine and parasitology was suffused with language that foregrounded nationalism, the tenor privileged conduct over race-commentators conceptualising research in terms of honour, duty, and service. Honour became a sticking point in Ross's priority disputes with Italian investigator Giovanni Battista Grassi. ${ }^{143}$ In a chapter of his memoirs entitled 'Roman Brigandage', Ross discussed the 'unscrupulous' behaviour of Italian researchers, insisting facetiously, 'great would have been their honour - if their honour had been greater'. ${ }^{144}$ Indeed, the ethos of sportsman-like fair play that characterised public school muscular Christianity also characterised discussions of parasitology research. When British neurophysiologist Charles Scott Sherrington (professor of physiology at Liverpool and later president of the Royal Society) wrote to congratulate Ross on his Nobel Prize, he perpetuated a narrative of honourable perseverance in the face of the dishonourable conduct of others:

It has been one of the most unmixed pleasures of my life to see your splendid discoveries make their way and overcome ignorance, prejudice and jealousy. The Nobel prize gains honour from its award to you. ${ }^{145}$

142 'Medicine in the Tropics' British Medical Journal 2.1969 (24 September 1898) 909-10 (p. 909).

${ }^{143}$ For a more detailed discussion of these disputes see: Emilie Taylor-Brown, "Petty Larceny" and "Manufactured Science": Nineteenth-Century Parasitology and the Politics of Replication' in Replication in the Long Nineteenth Century: Re-makings and Reproductions ed. by Julie Codell and Linda K. Hughes (Edinburgh: Edinburgh University Press, 2017) pp. 67-83.

${ }^{144}$ Ross, Memoirs, p. 410.

${ }^{145}$ London, LSHTM. RC. GB 0809 Ross/86/06/55 Letter from Ch. S Sherrington, n.d. 
Dr George Nuttall, founder and editor of both the Journal of Hygiene (1901) and Parasitology (1908), similarly used the idea of proper sportsmanship when writing to Ross about malaria research in 1913, 'you are the only man who shows the proper spirit of fair play. All the rest want to bag each other's game in a manner that disgusts me'. ${ }^{146} \mathrm{He}$ insists that 'scientific pirating' is rife within the international community, characterising the practice as 'new Koch methods', referring to Robert Koch's failure to cite the work of other researchers such as Ross, Grassi, and William MacCallum. ${ }^{147}$ Ross, Sherrington, and Nuttall's criticism of international conduct maps onto their investment in models of chivalry and crusader medievalism. As Mark Girouard explains

the ideal knight was brave, loyal, true to his word, courteous, generous [...] and respected and honoured his enemies in war, as long as they obeyed the same code as he did. Failure to keep to accepted standards meant dishonour. $^{148}$

The entrenchment of the directive to play fair in concepts of nationhood is illustrated by an encounter between Italian parasitologist Aldo Castellani and then Governor of British Ceylon Sir Robert Chalmers in 1914. Castellani trained at the London School of Tropical Medicine and under their auspices went out to Uganda to investigate sleeping sickness. He spent years working in the colonial medical services and was even reported as an 'English doctor' alongside British colleagues Cuthbert Christy and George Carmichael Low in journalistic accounts of sleeping sickness expeditions-his involvement with the British schools of Tropical Medicine providing him with an alternate form of nationhood informed by the science of empire. ${ }^{149}$ In 1914, he was offered a position as the first director of a new government department, the Research Institute of Science, in British Ceylon. However, his 'alien citizenship' stood in the way and he was asked to naturalise. When he turned down the position, explaining that changing his nationality would feel like 'denying [his] mother',

\footnotetext{
${ }^{146}$ London, LSHTM. RC. GB 0809 Ross/16/05. Letter from George Nuttall dated 13 April 1899.

${ }^{147}$ London, LSHTM. RC. GB 0809 Ross/16/04. Letter from George Nuttall dated 19 March 1899.

${ }^{148}$ Mark Girouard, Return to Camelot: Chivalry and the English Gentleman (New Haven: Yale University Press, 1981) p. 16.

${ }^{149}$ See, for example, 'Sleeping Sickness' Irish Independent, Tuesday 2 June 1903, p. 2.
} 
Chalmers professed that it had won him more respect, for 'could there be a better example of British fair-mindedness?'150 Britishness was, for Chalmers, so thoroughly tied to honour and fair play that Castellani could be legally Italian, but culturally British. Castellani later became director of tropical medicine at the Ross institute.

The 'knights of science' narrative provided a new field of research with a means by which to reconceptualise Britain's relationship to a global research community. Proponents employed mythic language that reached back to historical fantasies of nationhood in an attempt to elevate the discipline above the unglamorous realities of imperial competition and ultimately deployed these fantasies flexibly to suit professional and personal interests. From Manson's emphasis on producing a fully funded and competent scientific discipline to compete with French and German medicine, to Alfred Lewis Jones's concern for British-African commercial trade, to Ross's more poetic desire to conquer 'million-murdering death', proponents moulded the discipline to suit their own ends using the versatile concept of nationhood. ${ }^{151}$

Open Access This chapter is licensed under the terms of the Creative Commons Attribution 4.0 International License (http://creativecommons.org/licenses/ by $/ 4.0 /$ ), which permits use, sharing, adaptation, distribution and reproduction in any medium or format, as long as you give appropriate credit to the original author(s) and the source, provide a link to the Creative Commons licence and indicate if changes were made.

The images or other third party material in this chapter are included in the chapter's Creative Commons licence, unless indicated otherwise in a credit line to the material. If material is not included in the chapter's Creative Commons licence and your intended use is not permitted by statutory regulation or exceeds the permitted use, you will need to obtain permission directly from the copyright holder.

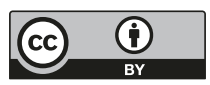

${ }^{150}$ Quoted in Aldo Castellani, Microbes, Men and Monarchs (London: The Scientific Book Club, 1960) p. 78.

${ }^{151}$ From his famous malaria day poem 'Reply'. Ronald Ross, 'Reply' (1897) Philosophies (London: John Murray, 1911) pp. 53-54 (p. 54). 